\title{
APPLICATIONS OF THE MARYBLYT COMPUTER MODEL FOR IDENTIFYING INFECTION RISK FOR FIRE BLIGHT OF APPLE
}

\author{
S.C. GOUK, R.J. BOYD and S.O. HUTCHINGS \\ Horticulture and Food Research Institute of New Zealand Ltd, \\ Ruakura Research Centre, Private Bag 3123, Hamilton, New Zealand
}

\begin{abstract}
The MARYBLYT computer model, Version 4.1, was used to identify fire blight blossom infection events on Royal Gala apple trees for the springs of 1993-1995 in Hawke's Bay, Nelson and Waikato. Over the three seasons, only one mid bloom infection was predicted in 1993 in a Hawke's Bay orchard. For all regions, several infection events were identified towards the end of flowering, but most of them occurred after petal-fall. Spray diary analysis indicated that streptomycin sprays that were applied during early to mid flowering were not targeted for the infection periods.
\end{abstract}

Keywords: Fire blight, Erwinia amylovora, disease prediction, integrated disease management

\section{INTRODUCTION}

Fire blight is a bacterial disease caused by Erwinia amylovora. The pathogen infects many Rosaceous plants including apple, pear, hawthorn, cotoneaster and pyracantha. Fire blight infects blossom, fruit, shoots and branches. With blossom blight, flowers turn black or brown and the whole flower cluster droops. The development of blossom blight is related to temperature because multiplication of E. amylovora is governed by temperature. Rain or moisture plays a part in spreading the bacteria from the stigmas, site of bacterial multiplication, to the nectarial cells where infection occurs (Thomson 1986).

Since blossom infections are primarily influenced by weather, the risk of infection can be identified by monitoring temperatures and rainfall. A computer model MARYBLYT (Lightner and Steiner 1990) has been developed to predict infection periods and is used to assist timing of control of fire blight in America (van der Zwet et al. 1994). The predictive criteria of both the MARYBLYT and the Thomson and Schroth (Thomson et al.1982) models were used to develop a prototype of a fire blight predictor in New Zealand (Manktelow 1993). Both the MARYBLYT model and the fire blight predictor have been trialed by growers and researchers (Manktelow, Tate pers. comm.). The MARYBLYT model has been evaluated for prediction of blossom blight in New Zealand since 1993 and has been shown to be accurate for predicting blossom blight on Royal Gala and Braeburn apple trees (Gouk et al. 1994, 1995). This paper focuses on the use of MARYBLYT for identification of blossom blight infection events for Royal Gala apple cultivar in three apple growing regions.

\section{Predictive criteria of MARYBLYT}

\section{METHOD}

MARYBLYT predicts disease through recognition of weather conditions suitable for infection during flowering. The conditions governing infection of blossom in MARYBLYT are:

(a) Presence of open flowers with stigmas and petals intact;

(b) Accumulation of at least 110 degree hours $>18.3^{\circ} \mathrm{C}$ after first bloom;

(c) Occurrence of dew or $\bullet 0.25 \mathrm{~mm}$ rain, or $\bullet 3 \mathrm{~mm}$ rain the previous day;

(d) An average daily temperature of $\bullet 15.6^{\circ} \mathrm{C}$. 
One degree hour is defined as one hour at one degree above the threshold temperature of $18.3^{\circ} \mathrm{C}$. Infection is assumed to occur once all of the above requirements have been met for susceptible hosts, and when the fire blight bacteria are present. Infection risk is considered medium or high if two or three of the criteria respectively have not been fulfilled. The first early symptoms of blossom blight are expected with the accumulation of an additional 57 degree days $>12.7{ }^{\circ} \mathrm{C}$ after the onset of an infection event.

\section{Prediction of blossom blight for 1993 - 1995}

Weather data, including daily maximum and minimum temperature, daily rainfall and crop phenology, were entered into the MARYBLYT programme to identify periods of blossom infection risk. In Hawke's Bay, weather information was obtained from automatic weather stations located in two orchards at Lawn Road (Hawke's Bay A) and Twyford (Hawke's Bay B), which are part of HortResearch's Orchard2000 weather station network. For comparison of the effects of regional climatic differences on blossom blight infection risks, weather information and and associated infection risk from two orchards in Waikato, at Newells Road (Waikato A) and Ohaupo Road (Waikato B), and one in Nelson were used. Weather information for Waikato A and Nelson orchards was obtained from stations located within the monitored orchard block, and from a nearby orchard for Waikato B.

Monitoring of blossom blight incidence

Blossom blight occurrence was monitored on Royal Gala apple trees in selected orchard blocks in each region. Orchards were monitored at 1-2 week intervals from bloom to the end of November. The same trees were inspected at each visit for presence of blossom blight strikes.

\section{Prediction of infection events}

\section{RESULTS}

The numbers of infection events recorded over three years for Hawke's Bay, Waikato and Nelson were grouped for different parts of the bloom period (Table 1). Over the three years, only one infection event was identified before mid-bloom (Hawke's Bay A, 1993). During late bloom (>95\% petal fall), infection events were recorded on only 4 out of 12 occasions in the 3 years. In all regions, most of the infection events occurred between complete petal-fall and the end of November, rather than during early to mid-bloom.

TABLE 1: Number of MARYBLYT predicted blossom blight infection events for Royal Gala apple trees in Hawke's Bay, Nelson and Waikato during the early and late bloom periods in 1993-1995.

\begin{tabular}{|c|c|c|c|c|c|}
\hline \multirow[b]{2}{*}{ Year } & \multirow[b]{2}{*}{ Region } & \multicolumn{3}{|c|}{ Infection Events } & \multirow{2}{*}{$\begin{array}{l}\text { High Risk } \\
\text { Early to } \\
\text { late bloom }\end{array}$} \\
\hline & & $\begin{array}{l}\text { Early to } \\
\text { mid-bloom }\end{array}$ & $\begin{array}{l}\text { Late } \\
\text { bloom }\end{array}$ & $\begin{array}{l}\text { Petal fall to } \\
\text { end November }\end{array}$ & \\
\hline \multirow[t]{2}{*}{1993} & Hawke's Bay A & 1 & 1 & 8 & 5 \\
\hline & Waikato & 0 & 0 & 0 & 3 \\
\hline \multirow[t]{5}{*}{1994} & Hawke's Bay 'A' & 0 & 3 & 1 & 0 \\
\hline & Hawke's Bay 'B' & 0 & 0 & 4 & 2 \\
\hline & Nelson & 0 & 0 & 0 & 1 \\
\hline & Waikato 'A' & 0 & 2 & 3 & 15 \\
\hline & Waikato 'B' & 0 & 4 & 2 & 7 \\
\hline \multirow[t]{5}{*}{1995} & Hawke's Bay 'A' & 0 & 0 & 0 & 3 \\
\hline & Hawke's Bay 'B' & 0 & 0 & 3 & 4 \\
\hline & Nelson & 0 & 0 & 2 & 2 \\
\hline & Waikato 'A' & 0 & 0 & 5 & 3 \\
\hline & Waikato 'B' & 0 & 0 & 4 & 4 \\
\hline
\end{tabular}


Findings in 1994 show that the dates blossom blight symptoms occurred coincided with predicted infection events for the late bloom period (Table 2). Blossom blight resulted from infection of flowers which were present at late bloom, or secondary flower flushes which were present after complete petal-fall of primary blooms. In the 1995 season, there were fewer blossom blight strikes found in the monitored orchards than in 1994 (Gouk unpublished data).

TABLE 2: Dates of blossom blight occurrence in relation to infection events for Hawke's Bay and Waikato orchards in 1994.

\begin{tabular}{|c|c|c|c|}
\hline Orchards & $\begin{array}{l}\text { Dates of predicted } \\
\text { infection }\end{array}$ & Growth stage & $\begin{array}{l}\text { Dates symptoms } \\
\text { appeared }\end{array}$ \\
\hline Hawke's Bay 'A' & $\begin{array}{l}6 \mathrm{Nov} \\
7 \mathrm{Nov} \\
8 \mathrm{Nov} \\
17 \mathrm{Nov}\end{array}$ & $\begin{array}{l}\text { late bloom } \\
\text { late bloom } \\
\text { late bloom } \\
\text { petal-fall - } \\
\text { secondary bloom }\end{array}$ & $\begin{array}{l}17 \text { Nov } \\
20 \text { Nov } \\
20 \text { Nov } \\
3 \text { Dec }\end{array}$ \\
\hline Waikato ' $A$ ' & $\begin{array}{l}8,9 \mathrm{Nov} \\
22 \mathrm{Nov}\end{array}$ & $\begin{array}{l}\text { late bloom } \\
\text { petal-fall - } \\
\text { secondary bloom }\end{array}$ & $\begin{array}{l}29 \text { Nov } \\
10 \mathrm{Dec}\end{array}$ \\
\hline Waikato 'B' & $\begin{array}{l}7,8,9 \text { Nov } \\
15,16 \mathrm{Nov}\end{array}$ & $\begin{array}{l}\text { late bloom } \\
\text { petal-fall - } \\
\text { secondary bloom }\end{array}$ & $\begin{array}{l}30 \mathrm{Nov} \\
12 \mathrm{Dec}\end{array}$ \\
\hline
\end{tabular}

TABLE 3: Examples of MARYBLYT output showing daily maximum, minimum and mean temperatures $\left({ }^{\circ} \mathrm{C}\right)$, daily rainfall and accumulation of degree hours (CDH) at monitored orchards which resulted in different infection risks between orchards on the same date.

Dates Location Max. Min. Mean Rainfall CDH Risk ${ }^{1}$ Flowering Temp. Temp. Temp. $\mathrm{mm}$

\begin{tabular}{|c|c|c|c|c|c|c|c|c|}
\hline 20.10 .93 & HB 'A' & 26.2 & 6.9 & 16.5 & 0.4 & 154 & I & mid bloom \\
\hline 20.10 .93 & Wai 'A' & 18.0 & 2.5 & 10.2 & 16.0 & 7 & M & mid-bloom \\
\hline 07.11 .94 & $\mathrm{HB}$ 'A' & 20.0 & 10.0 & 15.0 & 11.0 & 255 & $\mathrm{H}$ & late bloom \\
\hline 07.11 .94 & $\mathrm{HB}$ 'B' & 21.8 & 16.7 & 19.2 & 15.0 & 198 & I & late bloom \\
\hline 12.11 .94 & Wai 'A' & 19.0 & 5.0 & 12.0 & 0.0 & 333 & M & late bloom \\
\hline 12.11 .94 & Wai 'B' & 19.9 & 15.4 & 17.7 & 1.0 & 203 & I & late bloom \\
\hline 20.11 .95 & $\mathrm{HB}$ 'A' & 24.9 & 10.3 & 17.6 & 0.0 & 97 & M & petal-fall \\
\hline 20.11 .95 & HB ‘B’ & 24.0 & 10.8 & 17.4 & 0.8 & 289 & I & petal-fall \\
\hline
\end{tabular}

${ }^{1}$ MARYBLYT predicted infection risks - I: infection event, $\mathrm{H}$ - high risk, $\mathrm{M}$ - medium risk.

\section{Effects of weather conditions on infection risks}

Differences in the weather data and accumulation of degree hours which influence blossom blight infection are shown in Table 3. In 1993, Waikato A had a lower mean daily temperature and heat accumulation than Hawke's Bay A. In 1994, the difference between Hawke's Bay A and Hawke's Bay B' was due to a lower mean daily temperature at site A. However, in the following year, the difference was due to absence of rain at site $\mathrm{A}$. In Waikato, lower mean daily temperature and no rainfall was 
recorded in 1994 for Waikato A, while at Waikato B all the criteria for blossom infection were fulfilled.

\section{DISCUSSION}

The identification of only one infection event over early to mid bloom period during the three years for the three regions studied suggests that blossom blight is generally not a problem on Royal Gala apple trees during this period. The blossom blight strikes observed appeared to be caused by infection events which occurred mainly at the end of bloom periods (Gouk et al. 1994, 1995). Weather tends to limit infection risks over the main bloom period; from late bloom onwards weather may be conducive to infection but this is limited by scarcity of flowers. Hence in November, blossom infection would occur only if fresh flowers were present. Royal Gala and Braeburn apple trees have the tendency to produce secondary blooms and can be at risk if weather conditions are conducive to fire blight infection. In situations when infection events occurred after Braeburn or Royal Gala apple trees had finished flowering, no blossom blight was found because of the absence of susceptible blossoms (Gouk et al. 1995).

The data in Table 3 demonstrate that site to site variations occurred, and when one of the criteria was not fulfilled, infection risk varied. It should also be noted that the model only provides a guide on the effects of weather on infection risk. Users then need to consider factors such as presence of open flowers, bacterial inoculum, previous disease history and varietal susceptibility to arrive at a realistic conclusion on the actual risk of infection in the orchard.

Monitoring of infection risks could help the management of fire blight by identifying whether calendar streptomycin sprays are necessary. Currently, streptomycin is generally applied at $20 \%$ and $50 \%$ bloom. In the last three years, these applications may not have been necessary other than on one occasion in 1993 where protection may have been required in selected orchards where an infection event had occurred.

The model can be used to identify when fire blight symptoms occur, so that infected plant material can then be removed. Regular monitoring and removal of infected material is an important part of integrated disease management, which serves to provide early detection of the disease and minimise build up of bacterial inoculum in the orchard. The integrated approach will minimise risk for development of streptomycin resistance, prolong use of the only effective chemical during the growing season, and is more suited to the requirements of sustainable integrated fruit production systems to be implemented by ENZA.

\section{CONCLUSIONS}

Knowledge gained with use of fire blight predictive models will assist development of a window-based fire blight predictor which will become one of the modules of Orchard 2000.

\section{ACKNOWLEDGEMENTS}

Funding supports from FRST, ENZA and MAFPolicy.

\section{REFERENCES}

Anonymous, 1995. Decision Support software - Orchard $2000^{\mathrm{TM}}$. A product of Hortculture and Food Research Institute of New Zealand Ltd.

Gouk, S.C., Hutchings, S.O., Voyle, M.D., Hoyte, S.M. and Bedford, R.J., 1994. Evaluation of computer programmes for prediction of fire blight in pipfruit orchards. HortResearch Client Report No. 94/199. 32pp.

Gouk, S.C., Bedford, R.J., Hutchings, S.O., Cole, L. and Voyle, M.D., 1995. Evaluation of computer models for prediction of fire blight in pipfruit orchards. HortResearch Client Report No. 95/175. 49pp.

Gouk, S.C., Bedford, R.J., Hutchings, S.O., Cole, L. and Voyle, M.D., 1995. Evaluation of the MARYBLYT ${ }^{\mathrm{TM}}$ model for predicting fire blight blossom infections in New Zealand. Acta Horticulturae: (in press). 
Lightner, G.W. and Steiner, P.W., 1990. Computerization of blossom blight prediction model. Acta Horticulturae 273: 159-162.

Manktelow, D., 1993. Development of a computer-based fire blight prediction system. Report to the New Zealand Apple and Pear Marketing Board. 29 pp.

Thomson, S.V., 1986. The role of the stigma in fire blight infections. Phytopath. 76: 476-482.

Thomson, S.V., Schroth, M.N., Moller, W.J. and Reil, W.O., 1982. A forecasting model for fire blight of pear. Plant Dis. 66: 576-579.

van der Zwet, T., Biggs, A.R., Heflebower, R. and Lightner, G.W., 1994. Evaluation of the MARYBLYT computer model for predicting blossom blight on apple in West Virginia and Maryland. Plant Dis. 78: 225-230. 